\title{
KONFERENCJA „TORUŃSKIE ZBIORY PIECZĘCI” \\ Toruń, 19 listopada 2020 r.
}

\begin{abstract}
TKonferencja pt. „Toruńskie Zbiory Pieczęci” odbyła się w formie on-line \18 listopada 2020 roku. Zorganizowało ją Archiwum Państwowe w Toruniu oraz Wydział Nauk Historycznych UMK. Spotkanie dotyczące toruńskich zbiorów materiałów sfragistycznych stanowiło istotne przedsięwzięcie o charakterze naukowym oraz popularyzatorskim. Jego przygotowanie wiązało się także z zakończeniem realizacji projektu publikacji pierwszego zeszytu katalogu pieczęci przechowywanych w toruńskim archiwum: Pieczęcie królów i królowych polskich do 1572 r., finansowanego ze środków Naczelnej Dyrekcji Archiwów Państwowych.
\end{abstract}

Podczas spotkania wygłoszono osiem referatów, których wysłuchało w trybie zdalnym - blisko 80 uczestników. Głos zabierali badacze pieczęci, archiwiści oraz reprezentanci instytucji toruńskich przechowujących materiały sfragistyczne, wśród których wymienić można m.in.: Muzeum Okręgowe oraz Dział Zbiorów Specjalnych Biblioteki Uniwersyteckiej. Przez cały czas trwania konferencji uruchomiony był czat, za pomocą którego zarówno słuchacze jak i referenci mogli na bieżąco dzielić się swoimi uwagami oraz formułować pytania dotyczące także kwestii technicznych, co wpływało pozytywnie na usprawnienie transmisji.

Jako pierwsza głos zabrała dyrektor Archiwum Państwowego w Toruniu Beata Herdzin, tym samym oficjalnie rozpoczynając konferencję. Złożyła także podziękowania osobom zaangażowanym w stworzenie pierwszego zeszytu 
katalogu pieczęci oraz poprosiła o poprowadzenie pierwszej część spotkania Annę Laszuk (Naczelna Dyrekcja Archiwów Państwowych).

Pierwszym referentem był Marcin Hlebionek (Instytut Historii i Archiwistyki). Tematyka wystąpienia dotyczyła stanu rozpoznania oraz perspektyw edytorskich zasobu sfragistycznego Archiwum Państwowego w Toruniu. Na wstępie prelegent powołał się na dane statystyczne stanu opracowania zasobu sfragistycznego archiwów państwowych. Wskazał regułę opracowywania w pierwszej kolejności materiałów sfragistycznych występujących samoistnie, a zarazem na potrzebę sporządzania opisu pieczęci stanowiących cząstki archiwalne. Ponadto M. Hlebionek omówił etapy opracowania pieczęci z zasobu toruńskiego archiwum, począwszy od okresu staropolskiego oraz podał jakie informacje o obiektach archiwiści najczęściej utrwalają w pomocach archiwalnych. Odniósł się także do wykorzystywania zbiorów pieczęci przez badaczy, zwracając szczególną uwagę na badania Berharda Engela.

Kolejno głos zabrał Mateusz Superczyński (Archiwum Państwowe w Toruniu). Jego rozważania dotyczyły ewolucji pieczęci miast pruskich na przykładzie odcisków z Akt miasta Torunia. Referent omówił różne typy pieczęci występujące w miastach wielkich oraz mniejszych, m.in. Chełmnie, Toruniu, Golubiu, ze wskazaniem podobieństw oraz różnic. Doktor Superczyński przeprowadził analizę ikonograficzną pieczęci oraz okresów posługiwania się poszczególnymi w kancelariach miejskich. Ponadto objaśnił symbolikę odcisków, scharakteryzował legendy oraz właściwości fizyczne. Prelegent zaznaczył, że ewolucja przebiegała długo, a trakcie tego procesu wykształciły się znaki rozpoznawczo-własnościowe miast. Wskazał także na zasadę posługiwania się pieczęciami o rozmiarach adekwatnych do wielkości i znaczenia miejscowości oraz uwierzytelniania licznej korespondencji pieczęciami sygnetowymi przez miasta większe. W trakcie wystąpienia pokazana została prezentacja przedstawiająca zdjęcia omawianych kolejno pieczęci.

Następnym referentem był Janusz Bonczkowski (Archiwum Państwowe w Toruniu), który przedstawił zagadnienie ubytków w zasobie sfragistycznym toruńskiego archiwum na przykładzie pieczęci miejskich. Puntem wyjścia dla rozważań stały się katalogi pieczęci Bernharda Engela. Doktor Bonczkowski przedstawił ryciny odcisków zawarte w publikacjach oraz zestawił te odwzorowania z obecnym stanem zachowania opisanych pieczęci. Dla każdego miasta podał kilka przykładów odcisków, mi.in. Golubia, Brodnicy, Elbląga, Świecia, Chełmna. W prezentacji oprócz zdjęć pieczęci, prelegent zawarł opis wyobrażeń napieczętnych oraz teksty legend. Kończąc swoje wystąpienie, Bonczkowski omówił przyczyny złego stanu zachowania odcisków a także zaproponował 
kilka rozwiązań, które mogłyby spowolnić proces degradacji pieczęci przechowywanych w archiwach.

Po powyższym wystąpieniu zaplanowano krótką przerwę. Prowadzenie drugiej części konferencji objął Krzysztof Kopiński (Katedra Archiwistyki i Zarządzania Dokumentacją). Pierwszy referat tej części obrad wygłosiła Anna Szałańska (Archiwum Państwowego w Toruniu). Referentka przedstawiła zagadnienie szesnastowiecznych pieczęci cechów toruńskich jako cząstek archiwalnych, dołączonych do zbiorowego dokumentu przechowywanego w zasobie Archiwum toruńskiego. Rozważania rozpoczęto od podania podstawowych informacji na temat cechów oraz akt cechowych. Ponadto Szałańska omówiła konflikty cechów i władz miejskich, co bezpośrednio wiązało się z treścią dokumentu. Następnie ukazano funkcje pieczęci cechowych, znaczenie ich symboliki a także moc prawną. Pozwoliło to na szczegółowe omówienie kilkunastu pieczęci cechowych, których zdjęcia oraz opisy przedstawiono słuchaczom w prezentacji.

Aleksandra Mierzejewska (Muzeum Okręgowe w Toruniu) podczas swojego wystąpienia przybliżyła zebranym charakterystykę tłoków pieczętnych i odcisków lakowych ze zbiorów Muzeum. Prelegentka omówiła najstarsze oraz najbardziej interesujące obiekty z obszernej kolekcji materiałów sfragistycznych, z okresu od XIII do XX wieku. A. Mierzejewska wskazała dysponentów zachowanych pieczęci oraz opisała właściwości fizyczne typariuszy, przedstawiane przez nie wyobrażenia oraz legendy. Ponadto podała przykłady dokumentów, na których odciśnięto pieczęcie za pomocą omawianych tłoków. Referentka skupiła się także na artystycznych aspektach wykonania obiektów, podkreślając ich niezwykłą ornamentykę, chętnie prezentowaną na wystawach. Interesującym tematem poruszonym przez prelegentkę była geneza powstania oraz wartość badawcza zeszytów Juliusza E. Wernicke'go, zawierających wycięte z kopert odciski pieczętne.

Kolejny mówca, Mateusz Żmudziński (Archiwum Akt Dawnych Diecezji Toruńskiej) zaprezentował zbiór pieczęci oraz tłoków z zasobu tegoż archiwum, których ramy chronologiczne sięgają od XIV do XX w. Na początku wystąpienia referent zapoznał słuchaczy z okolicznościami powstania archiwum, jego kompetencjami oraz wskazał źródła pozyskiwania zasobu. Żmudziński zwrócił szczególną uwagę na najstarsze pieczęcie z zespołu Klasztor Cysterek-Benedyktynek Toruńskich, które wizualizowała dołączona prezentacja zawierająca opisy obiektów. Ponadto referent omówił pieczęcie biskupie, dziekańskie, parafialne. Przedstawiono także pieczęcie dysponentów świeckich, wśród których wyróżniono nowożytne pieczęcie królewskie. Prelegent odniósł się również do 
przechowywanych w zasobie Archiwum Diecezjalnego tłoków pieczętnych, wskazując zespoły, w których się zachowały.

W dalszej części konferencji głos zabrała Marta Czyżak (Gabinet Rękopisów Zbiorów Specjalnych Biblioteki Uniwersyteckiej), która wraz z Andrzejem Mycio przygotowała omówienie pieczęci znajdujących się w zbiorach Biblioteki Uniwersyteckiej. Marta Czyżak w swoim wystąpieniu skoncentrowała się na odciskach zachowanych w oddzielnej kolekcji dokumentów oraz pieczęciach znajdujących się w variach rodzinych. Referentka poinformowała o ponad stu dokumentach na których znajdują się odciski pieczętne bądź ślady po pieczęciach. Jako ich przykłady podała dokumenty proweniencji kościelnej, dokumenty królewskie oraz książęce, pochodzące z okresu XVI-XVIII wieku. Czyżak podkreśliła, że dużą część zbiorów stanowią pieczęcie sygnetowe, papierowo-lakowe oraz opłatkowe, odciśnięte na dokumentach rodzinnych i majątkowych. Najbardziej wyróżniającym się obiektem, jaki przedstawiła prelegentka był kodeks, na którego skórzanej oprawie odciśnięto kilka różnych pieczęci w określonej sekwencji, podzielonej na rzędy. Zdjęcia materiałów przedstawiono uczestnikom za pomocą prezentacji.

Ostatnią referentką była Jagoda Jankowska. Temat wystąpienia dotyczył omówienia wskazówek metodycznych do opisu materiałów sfragistycznych, bazujących na międzynarodowych standardach oraz opisie wielopoziomowym. Jankowska przedstawiła genezę oraz kształtowanie się metodyki opracowania materiałów sfragistycznych na gruncie międzynarodowym oraz w ujęciu polskim. Punktem wyjścia dla rozważań było omówienie modelu opisu pieczęci stworzonego w XIX w. we Francji oraz późniejszych propozycji badaczy z różnych krajów, dążących do standaryzacji opisu. Prelegentka przybliżyła także słuchaczom wykorzystywany obecnie standard ISAD (G), przystosowany do wielopoziomowego opisu pieczęci. W zakresie metodyki polskiej Jankowska szczególną uwagę zwróciła na wytyczne zaprojektowane przez NDAP i wydane w 1961 r., które do dziś wykorzystuje się w procesie inwentaryzacji oraz opracowania materiałów sfragistycznych. Na koniec poinformowała o pracach nad nowymi wytycznymi, które zakładają wielopoziomowy opis pieczęci z wykorzystaniem technologii informatycznych.

Po końcowym referacie rozpoczęła się dyskusja, do której zaprosił uczestników prowadzący obrady Krzysztof Kopiński. Pierwszy komentarz wygłosił Piotr Pokora, który stwierdził, iż wspólnie z M. Hlebionkiem doszli do wniosku, iż dla rozwoju badań nad sfragistyką niezbędne jest zorganizowanie ogólnopolskiej konferencji na temat zbiorów pieczęci. Pokora podkreślił potrzebę tworzenia edycji oraz opracowań poświęconych materiałom sfragistycznym ze zbiorów 
różnych archiwów, muzeów oraz bibliotek. Nawiązał także do kodeksu zaprezentowanego przez M. Czyżak oraz podał przykład starszej księgi „ozdobionej” w tożsamy sposób pieczęciami. Kolejno głos zabrał M. Hlebionek, odnosząc się do wystąpienia J. Bonczkowskiego i poruszając problem idealizacji wyobrażeń na rycinach pieczęci w publikacji Engela. Następna uwaga dotyczyła rozbieżności w zakresie podawanych w literaturze i rzeczywistych wymiarów tłoków ze zbiorów Muzeum Okręgowego. Hlebionek poddał pod dyskusję pomysł wydania katalogu tychże typariuszy, który mógłby uwzględnić nieznane szerzej, techniczne aspekty wykonania tłoków. Do dyskusji włączyła się także Anna Czajka z Centralnego Laboratorium Konserwacji Archiwaliów, która zachęciła do współpracy z pracowniami konserwatorskimi w zakresie ochrony pieczęci. Zwróciła uwagę na rolę nowoczesnych technologii cyfrowych (RTI), które oprócz tego że pozwalają na ochronę obiektów, to dzięki możliwości wykonania wysokiej jakości zdjęć, stanowią pomoc dla badaczy w zakresie odczytywania wyobrażeń i legend na pieczęciach zatartych. Anna Czajka ponadto wyraziła zainteresowanie czy w najnowszych wskazówkach znajdzie się miejsce na opis m.in. materiałów ochronnych pieczęci, takich jak puszki metalowe czy miski pieczętne. M. Hlebionek w odpowiedzi potwierdził pozytywy stosowania technologii cyfrowych podczas badań nad pieczęciami. Zwrócił jednak uwagę na to, że nie każdy badacz ma dostęp do takich rozwiązań, gdyż są one dość kosztowne. Stwierdził także, że w projekcie nowych wytycznych uwzględniono szerokie spektrum informacyjne, w tym aspekty konserwatorskie. A. Czajka wyjaśniła następnie kwestie związane z oprogramowaniem, tym samym tłumacząc iż omawiana technologia nie jest kosztowną inwestycją. P. Pokora również podzielił się swoimi doświadczeniami w korzystaniu z nowoczesnych rozwiązań podczas prac badawczych. Podobnie jak M. Hlebionek zwrócił uwagę, iż pracownicy archiwum nie zawsze dysponują wystarczającą wiedzą w zakresie identyfikowania materiału wykonania pieczęci. Wobec tego poparł propozycję organizowania dodatkowych szkoleń dla archiwistów celem dokształcenia ich w zakresie sfragistyki, tak by sporządzali prawidłowe opisy obiektów w inwentarzach. Pytanie do J. Jankowskiej odnośnie powstania nowszej wersji bazy SIGILLUM skierował z kolei K. Kopiński. Referentka odpowiedziała, że baza ta miała dwie wersje, natomiast do najnowszych wytycznych przystosowuje się je w formie bazy SFRAGIS. Dopowiedziała także iż wstęp, którym opatrzone będą wskazówki posłuży jako pomoc merytoryczna dla archiwistów w zakresie opisywania pieczęci.

Na zakończenie spotkania złożono podziękowania organizatorom konferencji, dyrektor Archiwum Państwowego w Toruniu Beacie Herdzin oraz Marcinowi Hlebionkowi. 
